\title{
10. Australian Sub-National Compacts with the Not-For-Profit Sector: Pathways to cross-sector cooperation
}

\author{
John Butcher
}

\section{Introduction}

In this chapter we trace the history of formal policy frameworks for crosssector cooperation in Australia's states and territories. Inspired by the original 'English' Compact, initiated by the Blair Labour government in 1998, the policy frameworks examined are intended to establish agreed rules of engagement between government (and its instrumentalities) and the not-for-profit (NFP) sector - especially those parts of the sector upon which government has become increasingly reliant for the delivery of public services.

Compacts represent an express acknowledgement by government of the contributions to social well-being made by civil society actors. They also embody the reciprocity implicit in the government-NFP sector relationship and are generally intended to act as a touchstone for agreed values, principles, attitudes and norms. To the extent that contemporary governments assert the intrinsic value of collaboration with non-state actors (O'Flynn and Wanna 2008) compacts offer symbolic proofs of a commitment to cross-sector partnership.

Most compacts also seek to alleviate the impact upon NFP service providers of externalities associated with government procurement and contracting processes that have tended to focus on the exchange of public funds for capability (service provision). Frequently cited as constraints on the capability and capacity of government's partners in the NFP sector are: high transaction costs; burdensome reporting; excessive prescription; failures to fund the true cost of service delivery; and operational uncertainty associated with short-term contracts (Productivity Commission 2010).

Here it must be noted that many NFP providers of contracted services reject the notion that they are merely contractors or agents. Rather, NFP organisations often see themselves as policy actors in their own right, with an implied mandate to represent constituencies of interest. NFP organisations are also repositories of 
expertise, knowledge and the custodians of stakeholder trust. So, in addition to exchanges of financial consideration for services rendered, contracting in the public services space involves exchanges of authority and legitimacy (Casey 2004).

Elson (2011, p. 137) observes that there have been few comparative analyses of framework agreements for cooperation at the sub-national level within the same country and this is certainly true of Australia, not least because the policy landscape is dynamic and still evolving. The analysis presented here is based upon extensive interviews undertaken between November 2010 and October 2011 with public officials, sector representatives and other policy actors in Australia's six states and the Australian Capital Territory. It is hoped that this work will make a useful contribution to both theory and praxis.

\section{Compacts in Australia}

In March 2010 the then Australian Prime Minister, Kevin Rudd, announced a national compact between the Commonwealth (federal) government and the country's NFP sector. The Commonwealth was a latecomer in this policy space (Butcher 2011, 2012; Butcher et al. 2012). For over two decades successive state and territory governments - most of them Labor governments - have looked to compacts to resolve the tensions and contradictions inherent in the contract state. This chapter tells the lesser-known story of these policy frameworks.

Between 2001 and 2012, compacts or compact-like policy frameworks have been actively considered in every Australian state and territory. Some have endured, some have fallen by the wayside, and others have failed to fully come to fruition. Some have enjoyed, and continue to enjoy a measure of success. Others have failed to earn the full confidence of stakeholders inside and outside government. The cross-sector policy frameworks implemented in each jurisdiction have differed in their scope, institutional arrangements and operational frameworks. Some were developed and agreed bilaterally between government and its NFP sector partners; others have taken the form of unilateral policy statements. Some purport to be whole of sector frameworks, while others are expressly focused on the health and social welfare sub-sectors.

In the discussion that follows, we consider the range of factors influencing the adoption of compacts as well as the factors contributing to their success and failure. Of course, it is not possible to examine each of the cases in detail in a chapter of this length. Nevertheless, the appendix at the end of the chapter provides a contextual snapshot of each state and territory. 


\section{Leading from below}

Australia is a federal state in which the constitutional division of powers confers primary responsibility upon states and territories for the delivery of health and human services, housing and education (ACT 2000b, p. 6; Casey et al. 2008c, p. 4). As a result, state and territory governments have a significant policy and financial exposure to the NFP sector. The rapid expansion of Australia's NFP sector through the 1970s and 1980s was largely underwritten by increases in social expenditure by state and territory governments. Today, income from state and territory governments represents a significant share of the aggregate recurrent income for Australia's community sector organisations (ACOSS 2011). ${ }^{1}$

From the mid-1990s, state and territory governments have confronted the twin challenges of fiscal pressures and increasing demand for public services including demands for greater choice in in relation to services and providers (Cook et al. 2012). In response, governments have sought - where politically and practically feasible - to ultilise non-state service providers in the NFP and for-profit sectors.

Human services account for a significant share of outsourced service delivery owing in part to the labour-intensive nature of these industries and the presumed lower cost structures prevailing in the NFP community services sector (Productivity Commission 2010, p. 249). Other advantages claimed for NFP service providers include greater nimbleness, responsiveness, acceptability to consumers and capacity for innovation (McDonald 1999; McDonald and Marston 2002).

Just as NFP service providers have become dependent upon government grants and contracts for a significant share of their income, so too state and territory governments have become dependent upon NFP service providers for the delivery of public policy and programs. Notwithstanding the interdependence of the public and NFP sectors, this is not a relationship of equals. A number of formal reviews have confirmed that NFP service providers often operate within significant constraints imposed by government policy, including high transaction costs, financial uncertainty, onerous reporting requirements, micromanagement, excessive focus on inputs, and failure to fund the full cost of service delivery (Auditor-General 2000; PAEC 2002; QAO 2007; VAGO 2010).

These factors help to explain why formal cross-sector policy frameworks to support enhanced cooperation between government and the NFP sector emerged

1 State and territory governments also exercise regulatory functions in relation to the NFP sector. The regulatory environment in which NFP organisations operate has been characterised as consisting of 'uncoordinated regimes at the Commonwealth and state/territory levels' in which '[d]isparate reporting and other requirements add complexity and cost, especially for organisations operating in more than one jurisdiction' (Productivity Commission 2010, p. 113). 
first in state and territory jurisdictions. However, it should also be noted that a compact between the Commonwealth government and the NFP sector was never in prospect at any time during the 11 years during which the centre-right Liberal-National Coalition governed nationally (Lyons 2001, 2002, 2003).

\section{Compacts and Labor governments}

As was the case federally, policy frameworks for cross-sector cooperation in states and territories (with only one exception, to be discussed later in this chapter) have been initiated by Labor administrations. In part this might be explained by the fact that the Australian Labor Party has strong historical and institutional associations with parts of what might be collectively termed 'civil society' (which includes the NFP sector), in particular the labour movement and progressive social movements. To the extent that centre-left political parties share values and constituencies with significant parts of the NFP sector, they might also exhibit a predisposition to enter into formal partnership frameworks based on an assumption that they and the sector are fellow travellers of a sort.

During the period of the Howard Coalition government (1996-2007) compacts with the NFP sector formed an important part of the policy palette in all Australian states and territories. During this period an especially antagonistic relationship prevailed between the federal government and parts of the NFP sector, particularly around the government's contracting practices and its intolerance of policy advocacy by the sector (Australia 2010; Productivity Commission 2010, pp. 309-310) - a situation that might have galvanised the sector to forge agreements with receptive state and territory Labor governments.

\section{Process streams analysis}

The adoption by state and territory governments of formal cross-sector policy frameworks exhibits features of policy transfer and/or policy convergence. Policy diffusion is evident where the preferred policy responses in one jurisdiction are systematically conditioned by prior choices made in others (Simmons et al. 2006, p. 787). The transmission between jurisdictions of public administration doctrines, such as those encompassed by new public management, are often thought of in these terms (Hood 1991; Common 1998; Halligan 2011). Policy convergence, on the other hand, is marked by a tendency for policy formulations to grow more alike in response to emerging problems (Drezner 2001). In other words, governments confronting similar problems might more or less independently come up with similar solutions. 
That formal cross-sector policy frameworks in Australia's states and territories contain substantially similar provisions and language is indicative of direct policy transfer (in so far as it reflects conscious and deliberate policy borrowing). However, cross-sector policy frameworks have emerged at different times and their political and practical expression differs substantially between jurisdictions, which is strongly suggestive of policy convergence. Explaining the emergence of compacts requires an analytic frame that supports a contextual analysis of the historical, political and institutional factors affecting the ways in which policy problems are framed and the roles played by policy actors in enabling (or impeding) the implementation of solutions (Common 2010).

Process streams analysis offers a useful approach for framing a plausible explanatory narrative. In his seminal book, Agendas, Alternatives and Public Policies (first published in 1984), Kingdon posed the questions 'what makes an idea's time come?' and 'what makes people in and around government attend, at any given time, to some subjects and not to others?' (Kingdon 1995, p. 1). Kingdon observed that in the volatile marketplace of ideas and solutions some ideas never gain traction, others become prominent and then fade, and some 'achieve lasting high agenda status' (Kingdon 1995, p. 116).

Kingdon posits the existence of three major 'process streams': the problem stream (for example, the emergence of consensus about problems that require resolution, such as the unintended externalities associated with contracted service delivery); the policy stream (for example, communities of policy 'specialists' in which alternative solutions to problems are formulated and tested, such as formal cross-sector framework agreements); and the politics stream (for example, events or circumstances that influence political receptiveness to problems and solutions, including swings in public opinion, interest group pressures, elections, changes of government, or machinery of government changes).

Although the three streams operate largely independently, they come together at critical times. When they do, they can result in the opening of a 'policy window', which offers a time-limited opportunity for new policy ideas to be placed on the policy agenda. In Kingdon's words: 'A problem is recognised, a solution is available, the political climate makes the time right for change, and the constraints do not prohibit action' (Kingdon 1995, pp. 86-88).

However, the opening of a policy window is not alone sufficient to place a proposal on the policy agenda. In most cases this requires the intervention of policy entrepreneurs who seek to couple their preferred solutions to existing problems. Policy entrepreneurs are people who have the connections, 
knowledge, profile and personal qualities necessary to promote the coupling of their preferred solutions with existing policy problems (Kingdon 1995, pp. $166-169,181-182) .^{2}$

Whether compacts survive the tumult of political contestation and policy implementation can depend on their maintaining what Kingdon refers to as 'high agenda prominence' (Kingdon 1995, pp. 103, 198). This can be especially challenging in environments characterised by multiple policy domains and in which individual and collective policy actors have differing values, priorities and operational norms. Compacts can also be crowded off, or down the policy agenda as a result of political turbulence in the form of events such as a change in leadership (a frequent occurrence in Australian politics in recent years), the loss or turnover of key personnel (such as a CEO of a public sector agency or an influential thought leader in the NFP sector) or by other crises that serve to refocus and re-prioritise the attentions of policymakers and implementers.

A decline in agenda prominence can also occur when decision-makers conclude that once the policy has been announced their mission has been accomplished. Framework documents - such as compacts - that enunciate the purpose and means for cross-sector cooperation can be potent policy markers. However, the crafting of such a document is not an end in itself; it is only a beginning. Without an implementation strategy and follow-through the legitimacy of the initiative and the opportunity to have a positive impact is compromised (AlmogBar and Zychlinski 2012). Other threats are institutional resistance (e.g. an effect of path dependence and isomorphism); disconnects between institutional narrative and organisational behaviour (Meyer and Rowan 1991); the failure to fully understand or accept the purpose of the policy framework; and unrealistic expectations (contributing to cynicism and a loss of legitimacy).

\section{Relevance in Australia}

Kingdon's process streams analysis offers a useful lens through which to view compacts and other forms of cross-sector agreement, but how might it apply in the Australian context?

First, in the problem stream, we have witnessed in Australia and elsewhere a broad consensus among policy practitioners and researchers about the range

\footnotetext{
2 Kingdon and other like-minded theorists (such as March and Olsen 2006) draw upon neo-institutionalist theory in their analysis of political and policy phenomena, bringing together strands of normative (institutional logics), rational choice (bounded rationality), and historical (path dependency) perspectives in a compelling synthesis. Kendall 2003, Brock 2008, Elson 2011, and Phillips 2003 each draw upon Kingdon in their analyses of compacts in the UK and Canada. Compacts might also be usefully examined through other lenses, including policy implementation (Elson 2006) or from a functional legal/administrative perspective (Bullain and Toftisova 2005).
} 
of tensions, contradictions and externalities associated with the contract state. These include failures to fund the full cost of service delivery, burdensome reporting and compliance requirements, and the substitution of competitive behaviours for collegiality among NFP service providers.

Second, in the policy stream, we have observed since 1998 the emergence within various policy communities of energetic policy discourses concerned with crosscutting or joined-up policy and implementation; social capital; public value; co-production; boundary-spanning, network and relational governance; and so on. Policy entrepreneurs within these same policy communities have at various times promoted compacts or similar frameworks as a means to realise crosscutting policy aims.

Third, in the politics stream, Australia's two major political parties have both embraced the central tenets of new public management. It is sometimes observed by political commentators that the 'professionalisation' of politics in contemporary Australia and the efforts of the Australian Labor Party (ALP) and the Liberal Party of Australia to command the political middle ground has left few points of policy difference between the two major parties (Johnson 2011; Aitkin 2013). Clearly signalling those points of political and policy difference - particularly in times of political change — is an essential part of political marketing. For this reason alone, the idea of a formal framework document, rich in political symbolism, might have great appeal in light of the social democratic and corporatist traditions of the ALP - especially if the framework does not result in a significant impost on government. ${ }^{3}$

\section{Australian cross-sector policy frameworks}

The analysis presented here is based upon an extensive review of relevant primary documents and a more limited secondary literature. The primary literature is replete with policy documents, press releases, correspondence and reports (including parliamentary reports, reports by state audit offices and consultants). This literature is invaluable in reconstructing the policy histories of the relationship frameworks in each jurisdiction.

Insights drawn from the literature are corroborated by in-depth interviews conducted with senior public officials, senior NFP sector representatives and other elite policy actors in each jurisdiction (with the exception of the Northern Territory). In order to protect the confidentiality of interviewees, none are identified by name or organisation.

3 Similar observations have been offered in relation to the Canadian Accord (Canada 2001) by Phillips 2003 and Brock 2004, 2008. 
Each of Australia's eight states and territories has explored the potential of formal relational frameworks between government and the community or voluntary sectors. Their form, content and implementation processes differ in each jurisdiction and sector confidence in state/territory frameworks is mixed - as is confidence in the effectiveness of compacts generally. It is difficult to neatly pigeonhole Australian state and territory policy frameworks. This is unsurprising given the complexity of the political and policy environments within which they arise, and the different perspectives and priorities brought to the table by the parties.

\section{A variety of forms}

The Australian Capital Territory (ACT) led the way in 2001 with what the government and the community sector proclaimed as 'the first Compact of its kind in Australia' (ACT 2001, p. 4). This first compact, initiated by a Liberal territory government, was subsequently adopted by a succeeding Labor government and remains an important touchstone for social policy in the ACT. The most recent framework agreement (at the time of writing) is the 2012 partnership agreement between the Tasmanian Department of Health and Human Services, the Department of Premier and Cabinet, and the community sector (Tasmania 2012). The Tasmanian agreement represents the culmination of an on-again/off-again conversation between government and the sector about a formal relationship framework begun in 1996 (personal communication 20111; Tasmania 2012).

To date, three jurisdictions have implemented bilateral framework agreements between a state or territory government and groups representing broad coalitions of NFP organisations. These are the ACT (the 'Social Compact'), New South Wales (NSW, with 'Working Together for NSW') and Queensland (the 'Queensland Compact'). Of these, only the 'Social Compact' continues to have policy relevance - helped by the fact that Labor has governed continuously in the Territory since 2001. ${ }^{4}$ By contrast, 'Working Together for NSW' had already declined in policy salience before the election of a Liberal-National Coalition state government in 2011. The 'Queensland Compact' — once considered an exemplar framework — was displaced by the election of a Liberal-National Party government in 2012. ${ }^{5}$

Cross-sector frameworks implemented in Victoria, South Australia and Tasmania have been more narrowly cast as agreements between state government departments - predominantly in the human services and community health

4 The next election will be held in October 2016.

5 It should be noted that neither 'Working Together for NSW' nor the 'Queensland Compact' were formally rescinded - as non-statutory instruments such a step is effectively moot. 
domains - and relevant NFP sub-sectors. In this, they are more explicitly concerned to address the legacy of problems arising in the contractual relationships between governments and NFP service providers. In Victoria, a proposal for a bilateral compact between government and the NFP sector was rejected in favour of domain-level partnership agreements between government departments and related groupings of NFP organisations. The first of these domain-level partnership agreements commenced in 2002 between the Department of Human Services and 'health, housing and community service organisations'. This agreement was renewed in 2009 (in the form of a memorandum of understanding) and the model has since been extended to other policy domains such as early childhood development.

Although the language of some of these framework documents - such as the 'Queensland Compact' - suggests broad application to the whole-of-government and the whole-of-sector, for the most part they apply to the human services and community services sectors. ${ }^{6}$ Although central agencies - for example, a premier's or chief minister's department - have had early involvement in the development of cross-sector frameworks in a number of jurisdictions (for example, in the ACT, New South Wales and Tasmania) in all cases the policy lead for these agreements resides primarily with line agencies with a policy lead in the human services domain.

Although all Australian jurisdictions have considered formal cross-sector policy frameworks, two - Western Australia (WA) and the Northern Territory (NT) - have followed a different path. In WA the 'Delivering Community Services in Partnership Policy' (Western Australia 201 lb) is not an agreement, although it was co-developed by government central agencies, key line departments, and NFP sector representatives. The policy was endorsed by the state cabinet, is strongly championed by the Premier and enjoyed the strong support of community sector leaders. The Northern Territory commenced the development of a framework agreement in 2004-05, but later abandoned these efforts. There were signs in 2011 that the NT Labor government might revisit the idea of a formal cross-sector framework (Henderson 2011; NT Government 2011), however, any such development was forestalled by the election in 2012 of a majority Country Liberal Party government.

6 This can also include community-based human services provided within a health portfolio. In Australia, the terms 'community services sector' or simply 'community sector' are frequently used to denote that part of the NFP sector providing community-based human services. 


\section{Centre-left versus centre-right}

With the exception of the $\mathrm{ACT}^{7}$ state and territory cross-sector policy frameworks were initiated under centre-left Labor governments - most during the period in which the centre-right Liberal-National Coalition governed nationally (1996-2007).

As long-standing state and territory Labor governments faltered under the weight of incumbency, frameworks for cross-sector cooperation were inherited by nominally conservative administrations. So far, five jurisdictions have elected centre-right governments: Western Australia in 2008, Victoria in 2010, New South Wales in 2011, and Queensland and the Northern Territory in 2012. Labor governments were narrowly returned in Tasmania and South Australia (SA) in 2010, and in the Australian Capital Territory in 2012 (in coalition with the ACT Greens).

Superficially, centre-left governments would appear to be the natural allies of the NFP sector. However, it has been observed by NFP policy actors in a number of jurisdictions that Labor governments often expect their NFP partners to be compliant, grateful, and to refrain from criticism. The following comment by a senior NFP sector official reflects a commonly expressed sentiment:

For many peak bodies, sometimes there's a perception that Labor governments are 'friendly towards them', but in fact, in lots of instances Labor governments expect peak bodies to be friendly towards them ...

Oftentimes, governments - particularly modern Labor governments have often misinterpreted that the place of peaks is to support them, and not to apply critical analysis and provide policy guidance from a point of independence (personal communication 2011c).

Another observed:

I can remember people on the Left of the ALP in New South Wales [expressing] exactly that view, you know, 'you should be damn grateful we're in and do what we want' - that sort of view, and I think the Left of the ALP still suffers from that in that 'we're the repository of all the good policy ideas' and at the end of the day the public sector still knows how to do it best. Sorry, I don't think either of those things are true (personal communication $2011 \mathrm{~b}$ ).

7 In April 2001, the Liberal government of the Australian Capital Territory published 'Compact: Community partnership ACT Government: the first step', which was hailed as 'the first Compact of its kind in Australia': Australian Capital Territory 2001, p. 4. Following a change of government in November 2001, the incoming Labor administration effectively rebranded and reissued the document as the Social Compact (2004) but without materially altering its contents: ACT 2000b, 2001. 
By contrast, Liberal-National governments can be more accepting of the legitimacy of NFP organisations as autonomous actors, particularly those embodying traditional liberal values of independence (from government), selfreliance and personal responsibility:

Oftentimes Liberal governments - I mean genuine liberal governments - sometimes appreciate the place of advocacy in a much clearer and less emotional manner and as a result are sometimes able to have much clearer relationships with bodies like peak bodies, because they see their place and they understand what it is (personal communication 2011c).

No two succeeding Liberal-National administrations exhibit identical policy responses. In New South Wales and Victoria Liberal-National governments continued to steer a course already set in train by previous Labor administrations: whereas the Victorian Coalition government continued along the constructive policy track established by Labor, in New South Wales an already moribund compact was ignored by the incoming government. Similarly, Western Australia's Liberal government (first elected in 2008 and re-elected in 2012) has enlarged upon policy foundations built by the previous Labor government and, in so doing, revived a stagnant government-NFP sector relationship.

In 2011, the Western Australia government announced its 'Delivering Community Services in Partnership Policy' (2011b) together with significant new investments aimed at ensuring the viability and sustainability of NFP enterprises in particular sub-sectors (Western Australia 2011a). In contrast, the Queensland Liberal-National Party (LNP) government, elected in a landslide in 2012, focused on reducing state expenditure. The 'Queensland Compact' was set aside and its governance mechanisms discontinued. So-called 'gag clauses' were re-inserted in service provision agreements to debar organisations from advocating for policy change or even including links on their website to other sites that advocate for legislative change (Queensland Law Society 2012). The Queensland NFP sector responded cautiously to these changes — presumably to avoid antagonising a government aggressively pursuing a program of fiscal consolidation.

\section{Policy windows and policy entrepreneurs}

Formal policy frameworks for cross-sector cooperation have been initiated during times of political and structural change. From the early 1990s Australian governments have wrestled, collectively and individually, with the challenges of reforming and modernising the economy and public administration. Greater choice, competition and contestability in public service provision required major improvements in public sector efficiency, responsiveness and effectiveness. Australian governments at all levels increasingly arrived at the conclusion that 
state predominance in public infrastructure, public utilities and public services could not be sustained. Market-testing, the separation of purchaser and provider functions, outsourcing, privatisation and purchase-of-service contracting were the new watchwords of Australian governance.

By the late 1990s there emerged in the problem stream a broad critique of the limitations, contradictions and externalities associated with new public management (see Pusey 2008). Meanwhile, in the policy stream, policy alternatives centred on notions of joined-up governance and more pluralistic approaches to the realisation of government's policy aims began to be promoted by state and non-state policy actors. Some of these proved to be skilled policy entrepreneurs capable of shaping policy preferences within government and the NFP sector.

From 1996-2007 the centre-right Liberal-National Coalition governed nationally. This was a government dedicated (ostensibly) to reducing the size and reach of the state, in part by leveraging competitive markets. For much of this period the centre-left ALP governed in Australia's states and territories. Although they too realised the necessity of structural reform, state and territory governments were also attracted to Blairite third way discourses then shaping social policy in the United Kingdom - discourses not unnoticed by thought leaders in the NFP sector, some of whom looked to compacts as a bulwark against the adverse impacts of contracting.

Policy windows opened at different times, under different circumstances and with different results in Australian states and territories. All states and territories have at one time or another embarked on the development of a formal crosssector policy framework. In a number of jurisdictions, however (NSW, WA, NT, Queensland) political turbulence in the form of leadership change, changes of government, structural change in the machinery of government and/or the departure of senior personnel (some of them the very policy entrepreneurs who caused compacts to be placed on the agenda in the first place) contributed to the closing of policy windows.

\section{Policy initiation, implementation and practice}

In some jurisdictions, central agencies and/or line departments have assumed the lead in top-down approaches to the development of cross-sector agreements, largely driven by a desire to resolve tensions arising in their contractual relationships with NFP service providers. Examples include South Australia (SA) and New South Wales. In others, the agreement-making process was initiated either by the sector itself in a bottom-up process (Queensland) or came about as the result of a bottom-up and top-down convergence of government and sector agendas (ACT, Tasmania, Victoria, WA). 
Each of the state and territory frameworks contains mutualistic elements, such as statements about the respective roles and contributions of the parties; shared principles, aims and objectives; and the standards of conduct expected of government and the sector. There are also notable differences between jurisdictions in terms of the role played by central agencies; the presence (or absence) of influential champions; the establishment of effective governance structures (including reporting and evaluation requirements); the formulation of action plans; the application of dedicated resources; and the degree of vertical and horizontal integration with related policy frameworks.

These factors can be important determinants of success. Any failure to institutionally embed formal framework agreements heightens the risks of fragmentation, inconsistency, irrelevance and cynicism - leading ultimately to a loss of policy salience. Even those policy frameworks that have enjoyed strong support within the NFP and public sectors can falter at critical moments in the politics stream, such as a change in leadership or a change of government. As observed by a key policy actor in Queensland, 'there is no real way to future proof documentation that carries a previous Premier's and Minister's picture' (personal communication 2010d).

\section{Policy impact}

The practical impact of cross-sector policy frameworks is difficult to gauge. It has to be borne in mind that in many respects these are aspirational frameworks. A compact represents an idealised relationship; the behaviours and practices set out in a framework document will not necessarily be mirrored on the ground at least not without investing effort in a process of managed change.

Examples of effective cross-sector policy frameworks are those operating in Victoria and WA. These are acknowledged by policy actors in the public and NFP sectors as having made a positive contribution to the quality and durability of the relationship between government and the human services sector. Both states also have dedicated units focused on issues of sustainability and capacitybuilding for the broader NFP sector (an Office for the Community Sector in Victoria, and a Community Engagement Unit in WA).

In both jurisdictions, governance structures have been established to guide implementation of the policy framework(s) and these exhibit a high degree of vertical and horizontal integration with allied policies. WA is notable in two respects: the government and the sector have eschewed a bilateral compact in favour of a comprehensive policy statement; and a centre-right government appears to have succeeded in negotiating a settlement with the sector where a centre-left government demonstrably failed. 
In Queensland, a state Labor government and the NFP sector accepted the need for a new settlement that would reflect their mutual dependence and underpin needed reforms. At its inception in 2008 the 'Queensland Compact' was regarded as an exemplar and even informed the development of the 'National Compact'. Implementation was guided by an action plan (Queensland 2008) overseen by a Compact Governance Committee (CGovC). The CGovC, headed by an Independent Chair appointed directly by the Premier, reported annually on compact achievements (Queensland 2009, 2010).

Following the election in 2012 of the LNP government led by Premier Campbell Newman, the CGovC ceased to meet and the Independent Chair was not renewed. The 'Queensland Compact' was no longer on the policy radar and the new government elected not to publish an external review of the compact completed prior to the election. The experience of the 'Queensland Compact' serves to illustrate the potential transience of cross-sector policy frameworks and the importance of obtaining cross-party support for the aims and aspirations they embody.

The contrasting circumstances of the ACT, SA and NSW are also instructive.

In the years since its launch in 2004 the ACT's 'Social Compact' (ACT 2004) had declined in visibility and relevance. Accepting the need to revive and revitalise their relationship, the ACT government and the community sector undertook to refresh the framework and a revised 'Social Compact' was launched in 2012 (ACT 2012). The ACT government, in partnership with the community sector, subsequently initiated a Community Sector Development Program to develop the skills and capabilities of the sector leaders to meet the reform pressures facing their organisations (personal communication 2013).

In SA, the framework agreement between the state government and the health and community services sector, 'Stronger Together' (South Australia 2009), was built upon foundations established by an earlier partnership agreement, 'Common Ground' (South Australia 2004). Billed as a 'reinvigorated approach between the partners to pool resources, resolve problems and develop new and creative approaches to service provision', candid accounts of public officials and sector representatives suggest divergent perceptions of the framework's effectiveness. Although state government officials speak highly of the framework (personal communication $201 \mathrm{lq}$ ) the assessment of a key policy actor in the NFP sector is far less positive (personal communication 2011c).

In NSW, a first-term Labor government placed a compact on the policy agenda as part of its platform for the 1999 state election. However, it was not until 2006 that the compact, 'Working Together for NSW' (NSW 2006), was finalised and launched - by which time the State Premier who had presided over its 
development, Bob Carr, had resigned. The long gestation of the agreement, together with the departure of key instigators in the public and NFP sectors, foreshadowed a fraught implementation process. By the time of the 2011 state election at which Labor lost government to the centre-right Liberal-National Coalition, 'Working Together for NSW' was widely acknowledged as a 'dead letter' - full of laudable words, but having had little discernable effect on the operations of government or the sector (Casey et al. 2008a; Dalton et al. 2008; Edgar and Lockie 2010; personal communication 2010a, 2010f, 2011b).

Australia's most recent cross-sector policy framework, the Tasmanian 'Partnership Agreement' between the Department of Human Services and Health, the Department of Premier and Cabinet and the community sector (Tasmania 2012) represents a policy coda to a decade-long conversation about the governmentsector relationship. Relations between the NFP sector and government in the island state are generally cordial and constructive. Like the ACT, Tasmania is a small jurisdiction in terms of both population and geography, and exhibits considerable mobility within and between the public and NFP sectors - factors that act to reduce barriers to cooperation.

At the time of writing the NT is the only jurisdiction that has not implemented a formal cross-sector policy framework. In 2004-05 the NT Labor government led by Clare Martin initiated consultations with the NFP sector about a framework agreement. However, the policy window closed abruptly when, in June 2007, the federal government announced a sudden and dramatic incursion into Aboriginal affairs in the NT - the Northern Territory Emergency Response (NTER) (Sanders 2008). The NTER was broadly interpreted as a rebuke to the NT Labor government and represented a significant loss of political capital for the Chief Minister, who resigned in November 2007 (Murdoch and Holroyd 2007). By 2011, senior figures in the NT government appeared to be revisiting the possibility of a formal cross-sector policy framework (Henderson 2011; NT Government 2011). However, Labor's defeat at the 2012 general election once again saw the policy window close. 


\section{Table 1: Effectiveness of policy instruments}

\begin{tabular}{|c|c|c|c|}
\hline \multicolumn{2}{|c|}{$\begin{array}{l}\text { Framework documents exhibiting some } \\
\text { effectiveness and durability }\end{array}$} & \multicolumn{2}{|c|}{$\begin{array}{l}\text { Framework documents exhibiting mixed } \\
\text { effectiveness }\end{array}$} \\
\hline $\begin{array}{c}\text { Delivering } \\
\text { Community } \\
\text { Services in } \\
\text { Partnership } 2011 \\
\text { (WA) }\end{array}$ & $\begin{array}{c}\text { Memorandum of } \\
\text { Understanding (MOU) } \\
\text { 2009-12/Partnership } \\
\text { Agreement 2010-14 } \\
\text { (VIC) }\end{array}$ & $\begin{array}{l}\text { Queensland } \\
\text { Compact } 2008\end{array}$ & $\begin{array}{c}\text { Social Compact } \\
2004 \text { and } 2012 \\
\text { (ACT) }\end{array}$ \\
\hline $\begin{array}{l}\text { - Unilateral } \\
\text { government policy } \\
\text { statement co- } \\
\text { developed with the } \\
\text { sector } \\
\text { - Policy lead shared } \\
\text { by central agencies } \\
\text { - Takes the place } \\
\text { of former Labor } \\
\text { government's } \\
\text { 'Industry Plan' } \\
\text { - Addresses practical } \\
\text { structural reform } \\
\text { agenda in relation } \\
\text { to pricing, funding, } \\
\text { red-tape, workforce } \\
\text { and capacity- } \\
\text { building } \\
\text { Oversight by } \\
\text { Partnership Forum } \\
\text { comprised of } \\
\text { departmental and } \\
\text { NFP representatives } \\
\text { - Achieving a } \\
\text { compact not a } \\
\text { priority for sector }\end{array}$ & \begin{tabular}{|l|} 
Formal bilateral \\
agreements between \\
Victorian government \\
line agencies (health \\
and human services \\
and early education) \\
and relevant parts of \\
the NFP sector \\
- Policy lead resides with \\
individual line agencies \\
- Complementary but \\
separate cross-sector \\
initiatives (Office for \\
the Community Sector, \\
2008) exist alongside \\
agreements \\
MOU model well \\
regarded by sector
\end{tabular} & \begin{tabular}{|l} 
Bilateral agreement \\
between state government \\
and the Futures Forum \\
on behalf of community \\
services sector \\
- Developed in response to \\
sector mobilisation around \\
the Community Services \\
Sector Charter (2007) \\
- Focus on structural reforms \\
to improve the government- \\
sector relationship and \\
to build the capacity of \\
the community services \\
sector Policy lead resides \\
with Department of \\
Communities \\
- Oversight by Compact \\
Governance Committee \\
(CGovC) \\
Independent Chair \\
appointed by Premier (now \\
lapsed) Reports annually on \\
Action Plan approved by \\
CGovC \\
- Compact in abeyance \\
following defeat of Bligh \\
Labor government in 2012 \\
state election
\end{tabular} & $\begin{array}{l}\text { - A Statement of } \\
\text { Understanding } \\
\text { between government } \\
\text { and the community } \\
\text { sector } \\
\text { - Focus mainly on } \\
\text { human services } \\
\text { - Policy lead resides } \\
\text { with health and } \\
\text { human services line } \\
\text { agency } \\
\text { - Oversight by Joint } \\
\text { Implementation Group } \\
\text { - Declining awareness } \\
\text { and impact since } \\
2004 \text { Social Compact } \\
\text { 'refreshed' in } 2012\end{array}$ \\
\hline
\end{tabular}

Source: Author's research. 
Table 1: Effectiveness of policy instruments continued

\begin{tabular}{|c|c|c|c|}
\hline \multicolumn{2}{|c|}{$\begin{array}{l}\text { Framework documents exhibiting minimal } \\
\text { impact }\end{array}$} & \multicolumn{2}{|c|}{$\begin{array}{l}\text { Framework documents recently established/ } \\
\text { not yet formalised }\end{array}$} \\
\hline $\begin{array}{l}\text { Stronger Together } \\
2009 \text { (SA) }\end{array}$ & $\begin{array}{l}\text { Working Together } \\
2006 \text { (NSW) }\end{array}$ & $\begin{array}{c}\text { Partnership } \\
\text { Agreement 2012-15 } \\
\text { (TAS) }\end{array}$ & $\begin{array}{l}\text { Common Cause } \\
2004 / 05 \text { (NT) }\end{array}$ \\
\hline $\begin{array}{l}\text { - Agreement between } \\
\text { community services } \\
\text { and health line } \\
\text { agencies and } \\
\text { relevant sub-sectors } \\
\text { - Policy lead resides } \\
\text { with line agency } \\
\text { Initiated by the } \\
\text { human services } \\
\text { line agency as } \\
\text { a mechanism to } \\
\text { manage relationship } \\
\text { with the sector } \\
\text { - Little evidence } \\
\text { of vertical } \\
\text { and horizontal } \\
\text { integration with } \\
\text { complementary } \\
\text { policy frameworks } \\
\text { for social inclusion } \\
\text { and volunteering } \\
\text { - Evidence of } \\
\text { disconnects in both } \\
\text { awareness and } \\
\text { application. }\end{array}$ & $\begin{array}{l}\text { - Bilateral agreement } \\
\text { between the state } \\
\text { government and } \\
\text { the Forum of Non- } \\
\text { Government Agencies } \\
\text { (FONGA) } \\
\text { - Purpose was to } \\
\text { strengthen working } \\
\text { relationships between } \\
\text { government and the } \\
\text { sector } \\
\text { - Focus mainly on } \\
\text { human services } \\
\text { and procurement } \\
\text { relationship } \\
\text { - Policy lead resides } \\
\text { with human services } \\
\text { line agency } \\
\text { - Oversight by Joint } \\
\text { Reference Group } \\
\text { - Few attributable } \\
\text { impacts } \\
\text { - Low levels of } \\
\text { awareness and } \\
\text { perceived relevance } \\
\text { - Policy widely regarded } \\
\text { by sector and } \\
\text { government agencies } \\
\text { as a 'dead letter' } \\
\text { - Liberal-National } \\
\text { government elected in } \\
2011 \text { has re-focused } \\
\text { on red tape reduction } \\
\text { and social impact } \\
\text { investment. }\end{array}$ & $\begin{array}{l}\text { - Partnership } \\
\text { Agreement between } \\
\text { DHHS, DPAC and the } \\
\text { Community Sector } \\
\text { launched by Premier } \\
\text { Laura Giddings in } \\
\text { October } 2012 \\
\text { - The Departments of } \\
\text { Health and Human } \\
\text { Services (DHHS) and } \\
\text { Premier and Cabinet } \\
\text { (DPAC) represent the } \\
\text { government } \\
\text { - Agreement is aligned } \\
\text { with the National } \\
\text { Compact and has } \\
\text { whole-of-government } \\
\text { implications. } \\
\text { Governed by the } \\
\text { Peaks' Network } \\
\text { and Government } \\
\text { Strategic Forum } \\
\text { which will prepare } \\
\text { an implementation } \\
\text { plan outlining } \\
\text { specific actions and } \\
\text { measurable targets } \\
\text { The Forum } \\
\text { will prepare an } \\
\text { annual report and } \\
\text { commission an } \\
\text { independent review } \\
\text { and evaluation at the } \\
\text { end of the first two } \\
\text { years }\end{array}$ & $\begin{array}{l}\text { - No formal instrument } \\
\text { for cooperation in } \\
\text { place } \\
\text { - An early attempt } \\
\text { to develop a } \\
\text { formal partnership } \\
\text { framework (Common } \\
\text { Cause, 2004/05) } \\
\text { was abandoned, } \\
\text { possibly as a } \\
\text { result of leadership } \\
\text { change (resignation } \\
\text { of Chief Minister, } \\
\text { Clare Martin) and } \\
\text { the Commonwealth } \\
\text { government's } 2007 \\
\text { NTER } \\
\text { - A 'conversation' } \\
\text { about a 'social } \\
\text { participation } \\
\text { framework' initiated } \\
\text { by Labor government } \\
\text { shortly before the } \\
2012 \text { election. } \\
\text { - Policy direction } \\
\text { unclear following } \\
\text { the formation of the } \\
\text { Country Liberal Party } \\
\text { government following } \\
\text { the } 2012 \text { general } \\
\text { election }\end{array}$ \\
\hline
\end{tabular}

Source: Author's research.

\section{Discussion}

The 'hollowing' of the state (Rhodes 2000, 2007; Di Francesco 2001) and the marketisation of social provision have deepened the mutual dependency between governments and the NFP sector; governments are increasingly dependent upon the NFP sector to deliver services, while NFP organisations are increasingly 
dependent upon government contracts for their income. ${ }^{8}$ Dependence has also contributed to a blurring of the boundaries between the public and NFP sectors to the extent that the latter has come to resemble the 'shadow state' foreshadowed by Wolch (1990) a quarter of a century ago.

Network approaches to governance have long been argued to present advantages over hierarchy or market as a means of adapting, coordinating and safeguarding exchanges in the face of demand uncertainty and task complexity (Jones et al. 1997). However, the promotion of network governance as a means to overcome the traditional, hierarchical model of government is a relatively recent phenomenon (Eggers 2008, p. 23). So-called 'third way' policy formulations emphasising joined-up approaches to governance have indeed lent impetus to the pursuit of more collaborative forms of cross-sector engagement, especially in the pluralist mixed economy of social provision. Even so, the capacity for bureaucratic, cultural and operational rigidity in the public and NFP sectors to subvert the stated aims of formal cross-sector policy frameworks should not be underestimated.

Abiding by the spirit and letter of compacts can be problematic for both sectors. Not only do compacts have no legal force, they are also susceptible to haphazard implementation and waning commitment. Despite underpinning commitments partnership and collaboration, aligning operational practices with the rhetoric of compacts can be problematic. Compacts also raise difficult questions about the nature, role and composition of the NFP sector as well as questions about the legitimacy of representative organisations and their authority to speak on behalf of a broader sector. The NFP sector is, after all, a diverse, variegated and sometimes unruly political space.

Compacts also serve to highlight the difficulty of effecting institutional change. Public sector organisations sometimes exhibit a deep (and increasingly anachronistic) attachment to command and control notions of governance, even when they are patently dependent upon third parties for the implementation and delivery of programs and services (Shergold 2008). NFP organisations, on the other hand, sometimes appear to regard contractual compliance and reporting as both an affront to their cultural and operational autonomy and an unnecessary regulatory impost with no intrinsic value (Shergold 2008, p. 7).

\footnotetext{
8 The 'hollowing out' thesis advanced by Rhodes, Di Francesco and others describes a state that has moved beyond the logics of 'command and control' to a greater reliance on networks and 'diplomacy' (Rhodes 2007). The hollowed-out state is characterised by external dependence and internal fragmentation that both weaken the central organising capacity of the state and challenges the executive's ability to 'steer' (Rhodes 2000, p. 350; Di Francesco 2001, p. 106). Characteristic of the 'contracting state', hollowing out raises normative questions about both the role of the state and the ability of the state to influence the direction and coherence of policy and outcomes (Di Francesco 2001, pp. 104-106).
} 
Curiously, there is little tangible evidence for the explicit adoption of policy learnings between states - even between states with Labor governments. The cases do suggest, however, that the rise and fall of compacts is closely associated with the opening — and closing — of policy windows occasioned by political events such as an impending, or recent elections, or changes in leadership. The cases also suggest that institutional neglect and complacency also contributes to a decline in the agenda prominence of cross-sector frameworks.

\section{Conclusion}

Do governments and the NFP sector need formal policy frameworks for crosssector cooperation? Clearly, key policy actors in Australia's states and territories have at various times concluded that they do. It is also clear that faith in the potential of such frameworks to materially reshape the relationship between governments and the NFP sector is frequently challenged.

Compacts are intended to provide a roadmap for navigating a tricky political and policy terrain. In so doing, they have the potential to confront and challenge prevailing notions about the respective cultural and operational norms that shape the identity and modus operandi of the public and NFP sectors. Where compacts come into existence against an historical backdrop of cross-sector cooperation; where they demonstrate joint ownership and a commitment to a concrete program of meaningful actions; where they are guided by sound governance and exhibit vertical and horizontal policy integration, compacts can serve to provide a space in which governments and the NFP sector can work collaboratively in achieving shared aims.

It is important to not underestimate the difficulty of promoting compacts across the breadth and depth of the public and NFP sectors. Here it is important to reflect on the fact that a compact is a process not a paper: some stakeholders will have low expectations of a compact (which might result in low levels of commitment), and others will expect the compact to solve all their problems (thus creating the preconditions for disappointment and disengagement). Managing expectations is critical.

A compact is not a magic bullet. However, the continuing interest in codifying the terms of engagement between the public and NFP sectors suggests that, despite their limitations, compacts — or something like them — will continue to form a part of the policy toolkit. 


\section{Postscript}

This paper was originally presented at the the Association for Research on Nonprofit Organizations and Voluntary Action (ARNOVA) Annual Conference in Toronto, in 2011. Although every effort has been made to bring the content up to date, the volatile nature of Australian politics makes this task difficult - if not impossible. The durability of compacts rests, as often as not, on the fortunes of government and the dominance at any given time of particular policy discourses. A change of government nationally in 2013 signalled abrupt changes in the direction of NFP policy in the federal sphere. It is too soon to tell whether the change of government in Tasmania (2014) will affect the tenor of the government/NFP relationship, and the implications of dramatic changes of government in Victoria (2014) and Queensland (2015) are as yet unknown. The imperative to reform and modernise the relationship between human services 'commissioners' and NFP providers was given added impetus by Peter Shergold, who was tasked to undertake a review by the Victorian government in 2013 (Shergold 2013). However, new funding modalities (via the National Disability Insurance Scheme) and experimental financial instruments (social impact bonds) have the potential to transform the foundations of that relationship and, perhaps, render compacts obsolete. 


\section{Appendix: A survey of Australian policy frameworks for cross-sector cooperation}

Although compacts have been part of the policy mix in Australian states and territories for over a decade, there have been few comprehensive surveys of the state of play and relatively little has been published in peer reviewed journals (Brown and Ryan 2003; Butcher 2006, 2011; Casey and Dalton 2006; Pugh and Saggers 2007; Baulderstone 2008; Casey et al. 2008a, 2008b, 2008c; Dalton et al. 2008; Edgar and Lockie 2010).

The landscape of the NFP policy space is changeable: political events can crowd compacts off the policy agenda; portfolio or machinery of government changes can result in a loss of continuity and salience; new problems and new solutions seize the attention of policymakers; neglect and complacency can fatally compromise even best-intentioned policy ideas. So it is that, almost as soon as one attempts to compile a definitive account of the range of policy responses in the states and territories, the accretion of policy change renders some part of the account obsolete. Nevertheless, the brief sketches presented below offer a useful glimpse of the situation in Australia's states and territories as at the time of writing.

\section{Vignette 1 - Australian Capital Territory: The social laboratory}

The Australian Capital Territory has a population of approximately 367,000, the majority of which live in Canberra, the national capital. Self-government was granted to the ACT in 1988 and the ACT's Legislative Assembly exercises the normal functions of a state legislature as well as local government functions. The Assembly's 17 members are elected using a Hare-Clark proportional representative electoral system and, from the time of its first election in 1989, minority governments have been the norm in the ACT, apart from 2004-08 when Labor (which previously headed a minority government elected in 2001) formed the Territory's first majority government. Following elections in 2008 and 2012 Labor has governed in coalition with the ACT Greens.

The ACT has been described as a 'social laboratory' — often in association with Labor governments (Fischer 1984). The ACT led the way with Australia's first compact in 2001 (ACT 2001), just months before the launch of the Canadian Accord. This was not a Labor initiative, however. Rather, the first ACT compact commenced under a minority Liberal government led by Chief Minister Gary Humphries (2000-01). 
In 2000, Humphries succeeded the previous Chief Minister Kate Carnell (19952000), following the latter's resignation in the face of a threatened no-confidence motion after a series of high-profile public scandals (Singleton 2001). That the Liberal government chose to pursue a compact was possibly motivated by a desire to ease long-standing tensions with the community sector ahead of the 2001 election (personal communication 2011a).

The 2001 compact continued to guide government policy after the election of a Labor minority government in 2001. It was republished in a revised edition in 2003 and was eventually replaced in 2004 with a rebadged and rebranded version of the previous government's compact. The new 'Social Compact' (ACT 2004) contained few material changes to the core provisions of the original. This is perhaps unsurprising given that in framing its pre-election budget, the previous Liberal government emphasised social spending in an attempt to outflank the centre-left Labor Party (Singleton 2001, pp. 587-588).

The impetus for the original compacts (Liberal and Labor) came from the Chief Minister's Department. Both the 'Social Compact' and an associated community sector funding policy were co-designed by public sector officials and government's community sector partners (personal communication 2011h, 2011i). However, a 'Functional Expenditure Review' undertaken in 2006 saw the policy lead transfer to the Department of Disability, Housing and Community Services which, by virtue of its share of contract and grants funding, was seen to have greater 'direct ownership of contracting policy' (personal communication 2011i).

Initially the 'Social Compact' stimulated interest in the NFP policy space and was seen to make a difference (personal communication 2011i). Although the sector acknowledged the compact's good intentions, it also expressed concern about a range of perceived problems with its operation (ACTCOSS 2008). Personnel changes, administrative reorganisations, and emerging processes also took a toll and the influence and visibility of the compact waned (personal communication $2011 \mathrm{i}$ ).

In 2011 a Joint Community-Government Reference Group (established in 2004 to oversight the 'Social Compact' and the community sector funding policy) undertook a review of the 'Social Compact'. One official observed that as a small jurisdiction in which ministers and senior executives are quite accessible, 'we're well-placed to get it right and to connect and communicate effectively with our community partners' (personal communication 2011h).

A refreshed 'Social Compact' was launched in June 2012 (ACT 2012). The 'Social Compact' is intended to complement the Canberra Plan, the 'Canberra Social Plan' and policy governing community engagement. Officials acknowledge the ongoing challenge of maintaining the relevance of policy frameworks, particularly as the principles and behaviours they engender become woven into 
practice (personal communication 2011h). One official looks forward to the day when policy frameworks mandating respect, equity and acceptance of diversity are regarded as anachronistic because these attitudes and behaviours have become ingrained (personal communication 2011i).

\section{Vignette 2 - South Australia: 'Stronger Together', or the weakest link?}

South Australia's key relationship framework document, 'Stronger Together' (2009) forms one part of a suite of policy documents and institutional arrangements that, in the words of a key policy actor from the NFP sector: 'probably don't hang together as neatly and as easily as we would necessarily like them to' (personal communication 2011c). Although portrayed in some quarters as an example of a well-functioning framework agreement (Baulderstone 2006), the South Australian example is also offered as a cautionary tale of a framework agreement hampered by weak institutional arrangements and a low level of executive commitment (ACOSS 2008).

'Stronger Together' and its predecessor document, 'Common Ground' (South Australia, 2004), were initiatives of the former SA Departments of Families and Communities, and Health. Although the NFP sector participated in drafting both agreements, the sector harboured 'a level of cynicism about the capacity of the agreement to change the nature of the relationship in a really fundamental way' (personal communication 2011c). Interviews with elite policy actors in the NFP sector, line agencies of government and central agencies reveal important 'disconnects' in the way the parties think about the effectiveness of the framework document and the overall health of the relationship between government and the sector.

There is a view, widely shared in the sector, that framework documents such as 'Stronger Together' serve symbolic as opposed to practical purposes: 'over the years government has wanted some instruments that can be paraded in a public context' (personal communication 2011c). One key NFP policy actor admitted being 'very sceptical and cynical about any real intention on the part of the government to behave in a manner that would be consistent with the "Stronger Together" agreement' (personal communication 2011c). Barriers in gaining access to the responsible Minister coupled with a bureaucracy with little latitude to negotiate the parameters of public policy, serves to diminish 'Stronger Together' as a mechanism for promoting robust policy discussion (personal communication 2011c).

Conversely, officials in the SA government line agency primarily responsible for the administration of the agreement consider that, on the whole, peak organisations are 'very happy' with 'Stronger Together': 'there's a great sense of ownership around 
it ... it gets referred to regularly within the Peaks Forum as a guide ... it holds a certain amount of power' (personal communication 2011j). One official suggested that there was a 'healthy tension' in the cross-sector relationship, pointing out that attempts by public sector agencies to partner effectively with peak organisations are sometimes made difficult by matters beyond their direct control (such as resourcing) while peak organisations sometimes 'respectfully decline' to work with line agencies 'because they're mad with the government' (personal communication 2011j).

The relationship between government and the sector in South Australia has been observed to vary 'from sub-sector to sub-sector, and from personality to personality' (personal communication 2011c) and was described by one senior central agency official as 'patchy'. The same official conceded that 'some agencies and individuals within agencies are doing very well and in other circumstances that's not the case', adding: 'It would be unfair to say there's a poor relationship across the board - it would [be] wrong to say that - nor could you say there are no issues at all' (personal communication 2011k). It is noteworthy that strong cross-sector relationships appear to exist in policy domains not covered by 'Stronger Together', such as the arts (personal communication 2011p).

South Australian central agencies exercise no oversight of cross-sector relationship frameworks. Although line agency officials suggested that some level of central agency coordination might be welcome, the suggestion was dismissed by one central agency official who observed, 'those days are gone' (personal communication $2011 \mathrm{k}$ ).

In smaller jurisdictions, such as South Australia, relationships between individuals often exert greater influence on the shape of the cross-sector discourse than official processes or institutional frameworks - both within and across domain boundaries, and between sector representatives and particular officials and/or ministers. This observation is echoed in other small jurisdictions such as the Australian Capital Territory and Tasmania.

\section{Vignette 3 - Victoria: 'Horses for courses'}

Reform to 'rationalise' the public sector reached its apotheosis in Victoria under the Liberal-National Coalition government led by Premier Jeff Kennett (1992-99) who 'eagerly embraced the neoliberal agenda of the economic policy think-tanks' (Economou 2006, p. 370). In 1992, the Coalition defeated a third-term Labor government mired in political crises. Asset sales, spending cuts, administrative consolidation and outsourcing formed the core of the new government's strategy, leading to Victoria being dubbed 'the contract state' (Alford and O'Neill 1994). In the process, the Victorian NFP sector, which has a long history of community engagement, was marginalised as a policy partner (personal communication 2011f, 2011n; Webster and Atkins 2011). The effect was a sector that was less 
collegial, faced greater uncertainty, and reported higher transaction costs and overheads flowing from the new contracting regime (personal communication $2011 n)$. Even so, contracting did leverage service change and fresh thinking (personal communication $201 \mathrm{ln}$ ).

The 1999 state election saw the Labor Party form a minority government. Premier Steve Bracks described his government as 'financially conservative and socially progressive' (Costar and Hayward 2005, p. 111). Labor made substantial investments in health, education and regional development, and 'did much to restore civility to public life after the divisiveness and sheer self-indulgence of Kennett's reign' (Dyrenfurth and Bongiorno 2011). The Bracks' government emphasised inclusivity (Hayward 2006) and advocated a partnership approach to human services delivery (PAEC 2002). Labor went on to win elections with working majorities in 2002 and 2006. A 2002 report found several problems associated with the complexity of service agreements for community, welfare and health services and pointed to work then occurring in overseas and Australian jurisdictions around the issue of formal partnership frameworks (PAEC 2002).

The Victorian community sector first advocated a compact as early as 2000 and most recently in 2006 (VCOSS 2006). Calls for a compact gained little traction, but the Premier's department offered strong support for achieving a better alignment between the Department of Human Services processes and the way community organisations work (personal communication 2011n). This led in 2002 to a partnership agreement between the Department of Human Services, the Victorian Council of Social Service, and the Victorian Health Care Association. The Partnership Agreement has been renewed periodically. Now in the form of a memorandum of understanding, the framework celebrates a strong, positive relationship based on trust, respect and collaboration and understanding (DHS 2009). However, its primary focus is streamlining funding arrangements and improving consistency (personal communication 2011f). Although parts of the sector have 'grumbled' from time to time, positive results have generated broad confidence in the DHS's - and the government's - commitment to the process (personal communication 2011f).

A compact is no longer a priority for the Victorian NFP sector, whose interests run more to practical matters such as pricing, funding and contracting arrangements, red tape reduction, data collection and workforce issues (personal communication 2011f). Reviews of NFP regulation (Victoria 2007a) and performance (Victoria 2007b) contributed to the establishment in 2008 of an Office for the Community Sector, initially within the Department of Planning and Community Development (now in the Department of Human Services). The Office for the Community Sector works with agencies and the sector to reduce compliance burdens, cut red tape, and strengthen sector capacity (personal 
communication 2011n). It has no role with respect to partnership agreements. The Bracks government also instituted a fixed price index mechanism that has worked 'remarkably well' over the last decade (personal communication 2011n).

The Victorian model of sector-specific frameworks begun under Labor continued under the Liberal-National Coalition government (personal communication $2011 n) ;$ a trend confirmed in 2010 with a separate partnership agreement in the early childhood development domain (Victoria 2010). The Coalition government, elected with a slim majority in 2010, sought to distance itself from the Kennett legacy (personal communication 2011f). Furthermore, the Black Saturday bushfires of 2009 and the floods of 2011 highlighted the constraints under which community services operate and strengthened the government's resolve to 'do everything they can to make it easier for those organisations to deliver' (personal communication $2011 n$ ). The Andrews Labor government, elected in 2014, has undertaken to work in partnership with the sector, possibly building upon the Community Sector Reform Council established by the Napthine Coalition government.

\section{Vignette 4 - Western Australia: Taking the road less travelled}

The relationship between government and the NFP sector in Western Australia has been evolving over a long time. In 2004, the WA Labor government initiated an 'Industry Plan' for the non-government human services sector with three broad objectives: improving the relationship between government and the sector; ensuring the viability and sustainability of non-government human services; and building sector capacity (Western Australia 2004). The plan was complemented by a policy statement on funding and purchasing community services (Department of Premier and Cabinet 2002), and an indexation policy for non-government human services (Department of Premier and Cabinet 2004). Both measures were strongly influenced by an earlier WA Auditor-General report that found significant shortcomings with the contracting regime used to procure services from NFP service providers (Auditor-General 2000).

Once considered a possible precursor to a compact, the 'Industry Plan' faltered owing to a lack of central agency leadership (personal communication 2011o), inconsistent implementation (personal communication 2011o), and a failure to enforce the application of policy guidance by line agencies (personal communication 2011 o, 2011g). As one central agency official commented:

There had been great policies launched in the past but then implementation had failed. Line agencies had gone back to 'bad behaviours'. We've had standard templates and approaches but everyone had butchered them along the way (personal communication 2011o). 
In 2008, the newly elected Liberal-National government established the Economic Audit Committee to conduct a wide-ranging audit of the efficiency and effectiveness of state government functions, including how government partners with the NFP sector to deliver community services (EAC 2009). Wishing to respond to the opportunities presented by an economic boom created by the State's mining industry, the new government initiated a change agenda built around a narrative of delivering better outcomes for Western Australians (personal communication 20110). This provided a 'platform for engagement' between government and the sector (personal communication 2011g). A 'Partnership Forum', comprised of public and NFP sector leaders and chaired by the former Secretary of the Prime Minister's Department, Dr Peter Shergold, was established in mid-2010 to address issues relating to social innovation; the resolution of long-standing problems with contracting; and historic failures to fund the full cost of services delivered by the NFP sector (personal communication 20110).

The 'Delivering Community Services in Partnership Policy', launched in July 2011 , is the centrepiece of a suite of administrative and financial measures aimed at rebuilding government's relationship with the sector and placing the sector on a more sustainable footing (Western Australia 2011b). Although it is not a bilateral agreement, the policy was extensively co-produced by government officials and sector leaders. As one close observer remarked: 'WACOSS [Western Australian Council of Social Service] has been almost joined at the hip with [the Department of] Premier and Cabinet throughout this process and I think that has raised some concerns actually, as regards its potential to been seen as supping with the devil' (personal communication 2011o).

There is a broad consensus amongst sector representatives and public sector officials that Shergold played a critical role by building trust and understanding amongst the participants in the process. Even more important has been the hands-on role played by Premier Barnett, which has given added impetus and authority to the change agenda: 'To have a First Minister that is driving this across government is quite important ... eighteen months in and he's still engaged in [the] process' (personal communication 2011o).

In its 2011-12 budget the state government committed \$604 million over four years to help redress the gap between the level of funding provided in state contracts and the actual cost of service delivery and an additional $\$ 400$ million for new services. One senior official suggested that there was genuine surprise in some quarters at the size of the spend: 'Only through actions can you demonstrate genuine listening and partnership' (personal communication 2011o). An ongoing challenge will be to sustain the momentum of change and the capacity of the sector to remain engaged in the policy and implementation process (personal communication $2011 \mathrm{~g}$ ). 


\section{Vignette 5 - Tasmania: The long conversation}

The 2012 Tasmanian 'Partnership Agreement' between the Department of Health and Human Services, the Department of Premier and Cabinet, and the community sector represented the culmination of an on-again/off-again conversation about a formal relationship framework begun in 1996 (personal communication 20111; Tasmania 2012). According to one official, the fact that the cross-sector relationship is mediated by a line agency is 'entirely problematic because it reduces the sector relationship essentially to a service delivery role', thereby reinforcing the emphasis on contracting and procurement (personal communication $2011 \mathrm{~m}$ ).

The extent of outsourced service provision in Tasmania has increased over time. With a population of 512,000 and a total land area of 68,401 square kilometres, Tasmania exhibits strong formal and informal connections both within the NFP sector and between the sector and government. The community sector is closely knit and there is a 'strong relationship' between the sector and government, based on 'a process of strong consultation in the way [government] forms its policies and the way it does its business' (personal communication 2011d). Tasmania's small size also serves to accentuate differences in the size and marketshare of NFP service providers, ranging from those with a part-time executive officer supported by volunteers through to large employing organisations - a prime example being Anglicare, which delivers services 'across absolutely every conceivable part of the community sector' (personal communication 2011d).

Personal relationships between state and non-state policy actors are also important: 'We hold a lot of store in the development of personal relationships', says one sector informant (personal communication 2011d). 'Everybody does know everybody', said a senior official (personal communication 20111). A downside is that cross-sector relationships are so often 'person dependent': 'a champion or a leader ... moves on and then things go splat' (personal communication $2011 \mathrm{e}$ ). Tasmanian ministers are highly accessible to the sector, and the Hare-Clark electoral system makes political compromise virtually unavoidable (Labor governed in Tasmania with the support of the Tasmanian Greens, two of whom were ministers in the government).

Partnership is an important theme in the State's political ecology: over recent years the Tasmanian government has entered into a number of partnership agreements with local councils and institutions such as the University of Tasmania. Social inclusion, social enterprise and place-based approaches have figured strongly as organising perspectives in Tasmanian social policy (personal communication $201 \mathrm{~lm}$ ). It can also be said that Tasmanian approaches reflect to some degree a diffusion of policy and praxis from the mainland, most noticeably from Victoria (personal communication 20111, 2011m, 2011e). 
At one time promoted within government as an indicator of success in forging effective cross-sector relationships (OCS 2009), by 2009 cross-sector discussions 'ran out of steam' (personal communication 2011l) — largely owing to personnel and structural changes in the Department of Health and Human Services (personal communication 2011d, 2011m).

In 2010, Peter Shergold was enlisted to help restart the conversation around a framework agreement (personal communication 2011l). Although initiated by the government, one official observed: 'I don't think the sector needed to be dragged kicking and screaming' (personal communication 2011m). The agreement 'very quickly became a joint enterprise', and, despite 'the normal suspicions that you would expect from the sector', key policy actors have reported high levels of good-will (personal communication $2011 \mathrm{~m}$ ).

A sector leader commented that 'there is a lot of hope resting on a partnership agreement', despite lingering cynicism within the sector (personal communication 2011e). The sector appears to accept the practical necessity for the policy lead to reside with the DHHS, nevertheless it is hoped that avenues will be found to eventually extend the footprint of the agreement to policy domains beyond traditional community services (personal communication 2011e). In the meantime, practical issues of workforce recruitment, retention and replacement are of primary concern (personal communication 2011l).

\section{Vignette 6 - New South Wales: A long road to nowhere in particular}

In New South Wales, the conversation leading to a formal policy framework around the government-sector relationship commenced in the mid-1990s (personal communication 2011b). As Australia's largest state, government agencies' operational and financial exposure to the NFP sector is enormous and has grown steadily as third party contracting grew in importance as a staple service delivery strategy.

The desire for a formalised relationship was driven by policies favouring greater competition in the procurement of public services (personal communication 2010a, 2011b). A difficult relationship between the sector and a State Coalition government (1988-95) was succeeded by an equally problematic relationship with a national Coalition government (1996-2007). The idea of a compact was largely 'sector driven', and a former Director of the New South Wales Council of Social Service, Gary Moore, played an early leading role (personal communication 2010f, a). Alarmed at the 'unfettered market change' that defined the mid-tolate-1990s, the sector (and Moore in particular) looked to the proposed 'English Compact' for inspiration (personal communication 2011b). 
A window of opportunity for change opened in NSW with the election of a Labor government in 1995. The new Labor Premier, Bob Carr, was receptive to the sector's proposal for a formal relationship framework, although there is a lingering view in the sector that Carr was less interested in fundamental change than he was in political branding in the lead-up to the 1999 state election (Casey et al. 2008a; Edgar and Lockie 2010; personal communication 2010a, 2011b). Negotiations on a compact commenced in 2001 and were conducted on behalf of the sector by the Forum of Non-Government Agencies - a coalition of peak and service provider organisations - and on behalf of government by the NSW Premier's Department.

It is noteworthy that the compact was being actively developed during a turbulent period of significant change in the modus operandi of the public and NFP sectors (personal communication 2010a). To some extent, the parties looked to the compact to resolve problems it was not designed to address. For example, the bureaucracy looked to the compact to drive rationalisation within the sector, while the sector looked to the compact to resolve competitive pressures and tensions amongst provider organisations (personal communication 2010a). The compact was sometimes used in an adversarial way to confront and criticise government. One official remarked that parts of the sector see government agencies 'as the big bag of money in the room' while failing to reflect on their own obligations under the compact (personal communication 2010c).

'Working Together for New South Wales' was launched in 2006 by Premier Carr just months before he resigned from politics. It came to be regarded by the sector as narrowly instrumental and overly focused on funding agreements (personal communication 2010a). Although originally intended to apply across government, the bureaucracy concluded this was not feasible owing to cultural, operational and institutional differences between human services sub-sectors (personal communication 2010f). Weak institutional design, machinery-ofgovernment changes, turnover of personnel, inconsistent representation and the loss of corporate memory all helped to undermine the legitimacy and relevance of the compact (personal communication 2010a).

Although there is no clear consensus on this point, it is possible that successive leadership changes in NSW contributed to the progressive marginalisation of 'Working Together'. The long gestation of the compact (1999-2006), coupled with personnel changes, also contributed to a loss of interest once it became policy (personal communication 2011b). With Carr's departure, suggested one observer, 'you almost immediately saw the Compact being put in the bottom drawer' (personal communication 2010a). 'Working Together' was virtually a 'dead letter' by the time of the Coalition victory at the 2011 state general election. The state government has not revisited the idea of a formal relationship framework although called upon to do so by the sector (NCOSS 
2011). Government continues to liaise with the sector on new policy initiatives such as 'social benefit bonds' (Treasury (NSW) 2012). For its part, the Forum of Non-Government Agencies has elected to emulate its Queensland counterpart by largely appropriating the Community Services Charter developed by the Futures Forum (FONGA 2011).

\section{Vignette 7 - Queensland: So near and yet so far}

In Queensland, a decade of state Labor government went by without any significant moves by either government or the NFP sector towards a formal relationship framework. An early top-down policy overture in this direction, 'Engaging Queensland' (Department of Families 2003), focused primarily on supporting volunteering as opposed to engaging the non-government sector in issues of policy or funding generally.

In August 2007, the Futures Forum, a coalition of peak and service provider organisations, launched a Queensland Community Services Sector Charter, the purpose of which was to 'to define and communicate to other sectors of society (Government, business and community) what the community services sector is, and to raise awareness of its vital role and invaluable contribution to society' (Futures Forum 2007). The Futures Forum was a response both to tensions in the government-sector relationship and those inherent in a diverse and fragmented sector (personal communication 2010b).

In September 2007, the charismatic and populist Premier, Peter Beattie, retired in favour of his deputy, Anna Bligh. The charter and leadership change coincided with a report by the Queensland Auditor General that found an excessive focus on compliance in state agencies' management of funding to nongovernment organisations (QAO 2007) and an internal review of the Department of Communities. The latter resulted in the publication of the 'Framework for Investment in Human Services' (Queensland 2007) — 'the absolute precursor to the Queensland Compact' (personal communication 2010e).

These events provided the impetus for action on government-NFP sector relations. Through the Framework, five major human services agencies, together with the Treasury, sought to establish clear and agreed funding processes. Said one official, this was about 'government getting its house in order' (personal communication 2010e). The charter added weight to efforts to address observed problems with the relationship, and the Futures Forum became the key interlocutor with government. A Joint Working Group was formed to oversee consultations about a compact and an associated 'action plan' - the rationale being that a compact without an action plan is 'happy words and not a whole lot else' (personal communication 2010e). 
The 2008 'Queensland Compact' became a touchstone for the 'National Compact'. A Compact Governance Committee (CGovC) was created (with a membership drawn from government and the sector) to which the Premier, whose personal political support was critical (personal communication, 2010b, 2010d, 2010e), appointed an 'Independent Chair'. The CGovC provided a 'safe and reliable forum for discussion' in which 'hard conversations' could occur and consensus reached about reform priorities (personal communication 2010d).

Although the Queensland Compact was extolled in some quarters as 'best practice' (personal communication 2010d), scepticism persisted amongst service providers who believed it constrained their capacity to maximise their interests. The dominant view, however, was one of cautious optimism: 'We knew, as it progressed, it was going to be a less than perfect vehicle but we felt, hey, it's going to be better than anything we've got, and there's no basis for these conversations at the moment, so why don't we have a go?' (personal communication 2010b).

The CGovC saw its role as moving a range of issues from being 'intractable' to 'just plain hard' (personal communication 2010d). The action plan developed to further the compact focused on concrete measures, process reforms and culture change. The CGovC, with secretariat support from the Department of Communities, gave the action plan a strong regional focus and reported annually against achievements.

A landslide defeat of the incumbent Labor government in the 2012 general election threw the compact into abeyance. The new government chose not to release an independent review of the compact, the CGovC was suspended and its independent chair was not reappointed. The Liberal-National Party (LNP) government focused on expenditure reductions and reimposed gag clauses in service procurement contracts. In 2015, the Queensland Council of Social Service (QCOSS) welcomed the formation of a minority Labor government as an 'opportunity to put the co-design and place-based solutions into action - with government, the community sector, community and the private sector working together to get the best possible outcomes for all Queenslanders'.

\section{Vignette 8 - Northern Territory: A relationship framework stillborn}

The Northern Territory does not, at present, have a formal policy framework for cross-sector cooperation. In 2005, the former Labor government led by Chief Minister Clare Martin (2001-07) engaged the firm RPR Consulting ${ }^{9}$ to assist with the development of a partnership framework between the NT government

9 RPR Consulting was one of two consulting firms engaged by the ACT Government to assist in the development of the Territory's first compact in 2001 (ACT 2000a). 
and the community sector. The consultant's final report, 'New Foundations', recommended the adoption of a 'Common Cause Charter' as a framework for future relationships between the government and community sectors. It also recommended the formation of a joint taskforce to steer the implementation of the proposed charter as well as the creation of a number of 'peak councils' (DCM 2004). By 2008, however, and despite initial good intentions, the taskforce had ceased to operate, leading to cynicism within the community sector (Casey et al. 2008c, p. 17; NTCOSS 2008).

Leadership change was a possible factor in the apparent abandonment of the process for developing a formal framework document in the NT. The then Chief Minister Clare Martin was the first female and the first Labor Chief Minister in the NT. Labor under Martin held a one-seat majority after the 2001 election and increased its majority in a landslide win at the 2005 election. The win might have provided added impetus for Martin's push for a new settlement with the sector.

In June 2007, the federal government led by John Howard, relying upon constitutional powers to override NT government jurisdiction in Aboriginal communities, announced the Northern Territory Emergency Response in response to the alarming prevalence of child sexual abuse in Aboriginal communities. The NT government's cooperation in the federal government's NTER was highly contentious. This was a show of political resolve on the part of the federal government in an election year. Although there was strident criticism of the NTER from a number of quarters, the federal government was on safe political ground: there was no political skin to be lost protecting Aboriginal children or in overriding a Labor government portrayed as failing to act on their behalf. Martin was surprised and seemingly unsettled by the move. The NT government was obliged to acquiesce and Martin's and Labor's credibility with the community sector was undermined.

Martin resigned suddenly in November 2007, citing the NTER as a factor (she was subsequently appointed as the Chair of the Australian Council of Social Service). At the 2008 NT election, Labor was returned with a one-seat majority under Martin's successor, Paul Henderson. The defection of a Labor MLA to the Country Liberal Party in 2009 led to a minority Labor government dependent upon the support of one independent MLA. Labor lost the 2012 general election, in part owing to a swing against it in Indigenous communities that comprise around 30 per cent of the NT population of 233,000.

It is likely that the NTER helped to push 'Common Cause' off the policy agenda. By 2011 there were signs of a possible reopening of the policy window, possibly influenced by the example of the National Compact. The former Chief Minister affirmed that 'building stronger relationships and creating opportunities to improve systems and support for non-government organisations' and 'reducing 
red tape' would be a priority of his government (Henderson 2011). In the area of child and family services, the NT Labor government called for ' $t$ t]he development of new partnerships with the non-government sector' (NT Government 2011). In mid-2012, Labor initiated a 'conversation' with Territorians about a 'social participation framework' that would clarify the respective roles of 'individuals, community groups, businesses, government agencies and non-government organisations' (DCM 2012).

Hot button social issues such as child protection, compulsory income management, substance abuse, domestic violence and youth justice dominate in the Territory. These issues disproportionately affect Indigenous communities, and policy responses must therefore take into account vast distances, small populations and geographically dispersed communities with complex needs. Political ructions in the territory have also offered distractions, such as when Chief Minister Terry Mills was controversially replaced as leader after only seven months in office while on an overseas trip and an abortive leadership coup was launched against his successor, Adam Giles, in 2015.

\section{References}

ACOSS (Australian Council of Social Service) 2008, 'National Compact Consultation: Final report'.

ACOSS 2011, 'Australian Community Sector Survey 2011', ACOSS Paper 173, Volume 1: National. Available at: http://acoss.org.au/images/uploads/ ACSS_2011_Report_Volume_1_National.pdf.

ACT 2000a, 'An ACT Compact on Relationships Between the Government and Community Sectors: Background briefing', ACT Government Chief Minister's Department, Canberra, October.

ACT 2000b, 'Focusing Partnership — Building Community: Towards a compact of understanding between the ACT Government and community sector', Government of the Australian Capital Territory.

ACT 2001, 'Compact: Community partnership ACT Government: The first step', Chief Minister's Department, Community Policy Unit.

ACT 2004, 'The Social Compact: A partnership between the community sector and the ACT government', Australian Capital Territory Government, Deptartment of Urban Services.

ACT 2012, 'The Social Compact: A relationship framework between the ACT Government and community sector', Australian Capital Territory 
Government, ACT Community Services Directorate. Available at: http:// www.communityservices.act.gov.au/_data/assets/pdf_file/0009/130140/ Social_Compact.pdf.

ACTCOSS (ACT Council of Social Service) 2008, 'Finding Solutions: Towards the long term viability of the ACT community sector'. Available at: http://www. actcoss.org.au/publications/Publications_2008/2108REP.pdf.

Aitkin, D. 2013, 'Labor and the Liberals: The real differences'. Available at: http://donaitkin.com/labor-and-the-liberals-the-real-differences/.

Alford, J. L. and D. O'Neill (eds) 1994, The Contract State: Public manangement and the Kennett government, Centre for Applied Social Research, Deakin University, Melbourne.

Almog-Bar, M. and E. Zychlinski 2012, 'A Façade of Collaboration', Public Management Review 14, pp. 795-814.

Auditor-General 2000, A Means to an End: Contracting not-for-profit organisations for the delivery of community services, Office of the Auditor-General, Western Australia.

Australia 2010, 'National Compact Between the Australian Government and the Third Sector', Consultation Report, Commonwealth of Australia, February.

Baulderstone, J. M. 2006, 'Changing Relationships Between the Public Sector and Community Service Organisations: Insights from the South Australian case', paper delivered to Public Policy Network Conference, Adelaide, South Australia.

Baulderstone, J. M. 2008, 'Changing Relationships Between the Public Sector and Community Service Organisations: Insights from the South Australian case', Public Policy, 3(1), pp. 1-16.

Brock, K. L. 2004, 'The Devil's in the Detail: The Chretien Legacy for the third sector', Review of Constitutional Studies 9, pp. 263-283.

Brock, K. L. 2008, 'Policy Windows and Policy Failures: Using Kingdon to explain the later life cycle of the voluntary sector initiative', paper delievered to Canadian Political Science Association meeting, University of British Columbia. Available at: http://www.cpsa-acsp.ca/papers-2008/Brock.pdf.

Brown, K. and N. Ryan 2003, 'Redefining Government-Community Relationships Through Service Agreements', Contemporary Issues in Business and Government 9, pp. 21-30. 
New Accountabilities, New Challenges

Bullain, N. and R. Toftisova 2005, 'A Comparative Analysis of European Policies and Practices of NGO-Government Cooperation', International Journal of Not-for-Profit Law 7, pp. 64-112.

Butcher, J. 2006, 'Government, the Third Sector and the Rise of Social Capital', Third Sector Review 12, pp. 69-88.

Butcher, J. 2011, 'An Australian Compact with the Third Sector: Challenges and prospects', Third Sector Review 17, pp. 35-58.

Butcher, J. 2012, 'The National Compact: Civilising the relationship between government and the not-for-profit sector in Australia', in R. Laforest (ed.), Government-Nonprofit Relations in Times of Recession, McGill-Queen's University Press, Toronto.

Butcher, J., J. Casey and B. Dalton 2012, AAn Australian National Compact: Something old, something new?', Nonprofit Policy Forum 3(2).

Canada 2001, 'An Accord Between the Government of Canada and the Voluntary Sector', Government of Canada.

Casey, J. 2004, 'Third Sector Participation in the Policy Process: A framework for comparative analysis', Policy and Politics 32, pp. 241-257.

Casey, J. and B. Dalton 2006, 'The Best of Times, The Worst of Times: Communitysector advocacy in the age of compacts', Australian Journal of Political Science 41, pp. 23-38.

Casey, J., B. Dalton, R. Melville and J. Onyx 2008a, "'An Opportunity to Increase Positive Results" or "So Disappointing After So Much Energy"?: A case study on the long gestation of working together for NSW', Centre for Australian Community Organisations and Management Working Paper, University of Technology Sydney.

Casey, J., B. Dalton, J. Onyx and R. Melville 2008b, Advocacy in the Age of Compacts: Regulating government-community sector relations International experiences', Centre for Australian Community Organisations and Management Working Paper No. 76, University of Technology Sydney.

Casey, J., B. Dalton, J. Onyx and R. Melville 2008c, 'Advocacy in the Age of Compacts: Regulating government-community sector relations in Australia', Centre for Australian Community Organisations and Management Working Paper No. 78, University of Technology Sydney.

Common, R. K. 1998, 'Convergence and Transfer: A review of the globalisation of new public management', The International Journal of Public Sector Management 11, pp. 440-450. 
Common, R. K. 2010, 'When Policy Diffusion Does Not Lead to Policy Transfer: Explaining resistance to international learning in public management reform', paper delivered to 14th International Research Society for Public Management Conference, University of Berne.

Cook, B., V. Quirk and W. Mitchell 2012, The Impact on Community Services of Staff and Service Reductions, Privatisation and Outsourcing of Public Services in Australian States, Centre of Full Employment and Equity, University of Newcastle, Newcastle.

Costar, B. and D. Hayward 2005, 'Steve Bracks: Victoria's "nice guy" who won against the odds', in J. Wanna, J. and P. D. Williams (eds), Yes Premier, UNSW Press, Sydney.

Dalton, B., J. Casey, J. Onyx, R. Melville and F. Lockie 2008, 'Advocacy in the Age of Compacts: NSW community sector workers speak about their experiences', Centre for Australian Community Organisations and Management Working Paper, University of Technology Sydney.

DCM (Department of the Chief Minister) 2004, 'Common Cause Taskforce Terms of Reference: A partnership between the Northern Territory Government and the community', Government of the Northern Territory.

DCM 2012, 'Social Participation Framework', Government of the Northern Territory. Available at: http://www.dcm.nt.gov.au/strong_community/ social_participation_framework.

Department of Premier and Cabinet 2002, 'Funding and Purchasing Community Services: A policy statement on a fresh approach to funding and purchasing relationships with not-for-profit sector', Western Australian Government.

Department of Premier and Cabinet 2004, 'Western Australian Government Indexation Policy for the Non-Government Human Services Sector', Western Australian Government.

DHS (Department of Human Services) 2002, 'Partnership Agreement: Partnership in practice', Government of Victoria.

DHS 2009, 'Memorandum of Understanding 2009 to 2012: Between the independent health, housing and community sector and the Department of Human Services', Government of Victoria.

Di Francesco, M. 2001, 'Process not Outcomes in New Public Management?: "Policy coherence" in Australian government', The Drawing Board: An Australian Review of Public Affairs 1, pp. 103-116. 
New Accountabilities, New Challenges

Department of Families 2003, Engaging Queensland: The Queensland Government Policy on Volunteering, Department of Families, Brisbane.

Drezner, D. 2001, 'Globalization and Policy Convergence', International Studies Review 3, pp. 53-78.

Dyrenfurth, N. and F. Bongiorno 2011, A Little History of the Australian Labor Party, UNSW Press, Sydney.

EAC (Economic Audit Committee) 2009, 'Putting the Public First: Partnering with the community and business to deliver outcomes', Final Report.

Economou, N. 2006, 'Jeff Kennett: The larrikin metropolitan', in P. Strangio and B. J. Costar (eds), The Victorian Premiers 1856-2006, The Federation Press, Annandale.

Edgar, G. and F. Lockie 2010, 'Fair-Weather Friends: Why compacts fail nongovernment organisations', International Journal of Sociology and Social Policy 30, pp. 354-367.

Eggers, W. D. 2008, 'The Changing Nature of Government: Network governance, in J. O'Flynn and J. Wanna (eds), Collaborative Governance A new era of public policy in Australia?, ANU E Press, Canberra.

Elson, P. 2011, 'The Emergence of Structured Subnational Voluntary Sector Government Relationships in Canada: A historical institutional analysis', Voluntary Sector Review 2, pp. 135-155.

Fischer, K. F. 1984, Canberra, Myths and Models: Forces at work in the formation of the Australian capital, Institut für Asienkunde, Hamburg.

FONGA (Forum of Non-Government Agencies) 2011, 'The New South Wales Community Sector Charter', Council of Social Service of New South Wales, Sydney.

Futures Forum 2007, 'Queensland Community Services Sector Charter'. Available at: http://www.qcoss.org.au/sites/default/files/the-charter.pdf.

Halligan, J. 2011, 'NPM in Anglo-Saxon Countries', in T. Christensen and P. Lægreid (eds), The Ashgate Research Companion to New Public Management, Ashgate Publishing Co., Farnham, Surrey and Burlington.

Hayward, D. 2006, 'Steve Bracks: The quiet achiever', in P. Strangio and B. J. Costar (eds), The Victorian Premiers 1856-2006, The Federation Press, Annandale. 
Henderson, P. 2011, 'Strengthening Relationships Between the Non Government Sector and Territory Government', Northern Territory Government. Available at: http:/www.territorystories.nt.gov.au/bitstream/handle/10070/236981/ Henderson-041111-Strengthening_relationships_between_the_non_ government_sector_and_Territory_government.pdf.

Hood, C. 1991, 'A Public Management for all Seasons?', Public Administration 69 , pp. 3-19.

Johnson, C. 2011, 'Gillard, Rudd and Labor Tradition', Australian Journal of Politics and History 57, pp. 562-579.

Jones, C., W. S. Hesterly and S. P. Borgatti 1997, 'A General Theory of Network Governance: Exchange conditions and social mechanisms', The Academy of Management Review 22, pp. 911-945.

Kendall, J. 2003, The Voluntary Sector, Routledge, London.

Kingdon, J. W. 1995, Agendas, Alternatives, and Public Policies, Longman, New York.

Lyons, M. 2001, 'Compacts Between Governments and the Voluntary Sector', paper delivered to conference 'Governance and Partnerships in the Third Sector: Reconciling Agendas for Change', Melbourne, 27 April. Available at: http://www.communitybuilders.nsw.gov.au/compacts.pdf.

Lyons, M. 2002, 'Institutional Prerequisites for Successful Compacts Between Governments and the Third Sector or Why a Compact is not yet possible in Australia', paper delivered to Sixth Australian and New Zealand Third Sector Research Conference, Auckland.

Lyons, M. 2003, 'Improving Government-Community Sector Relations', The Journal of Contemporary Issues in Business and Government 9, pp. 7-20.

March, J. G. and J. P. Olsen 2006, 'Elaborating the "New Institutionalism"”, in R. A. W. Rhodes, S. Binder and B. Rockman (eds), The Oxford Handbook of Political Institutions, Oxford University Press, Oxford.

McDonald, C. 1999, 'The Third Sector in the Human Services: Rethinking its role', in I. O'Connor, J. Warburton and P. Smyth (eds), Contemporary Perspectives on Social Work and the Human Services: Challenges and change, Longman, Frenchs Forest.

McDonald, C. and G. Marston 2002, 'Fixing the Niche?: Rhetorics of the community sector in the neo-liberal welfare regime', Just Policy 27, 3-10. 
Meyer, J. W. and B. Rowan 1991, 'Institutionalised Organisations: Formal structure as myth and ceremony', in W. W. Powell and P. J. DiMaggio (eds), The New Institutionalism in Organizational Analysis, University of Chicago Press, Chicago and London.

Murdoch, L. and J. Holroyd 2007, 'Clare Martin and Deputy Quit', Sydney Morning Herald, 26 November 2007.

NCOSS (NSW Council Of Social Service) 2011, 'NCOSS News', March. Available at: http://www.ncoss.org.au/votelfairness/NCOSS-News-2011-electionissue.pdf.

NSW 2006, 'Working Together for NSW: An agreement between the NSW Government and NSW non-government human services organisations', NSW Department of Community Services and the Forum of Non-Government Agencies.

NT Government 2011, 'Safe Children, Bright Futures: Strategic Framework: The Northern Territory Government response to the report of the board of inquiry into the child protection system in the Northern Territory' ${ }^{\prime}$, Northern Territory Department of Children and Families.

NTCOSS (Northern Territory Council of Social Service) 2008, 'Annual Report'.

OCS (Office for the Community Sector) 2009, 'Office for the Community Sector Newsletter', Department of Health and Human Services, Hobart.

O'Flynn, J. and J. Wanna (eds) 2008, Collaborative Governance: A new era of public policy in Australia?, ANU E Press, Canberra.

PAEC (Public Accounts and Estimates Committee) 2002, 'Report on the Department of Human Services: Service agreements for community, health and welfare services', Parliament of Victoria.

Phillips, S. D. 2003, 'In Accordance: Canada's voluntary sector accord from idea to implementation', in K. L. Brock (ed.), Delicate Dances: Public policy and the nonprofit sector, McGill-Queen's University Press, Kingston.

Productivity Commission 2010, 'Contribution of the Not-for-Profit Sector'.

Pugh, J. and S. Saggers 2007, 'Cross-Sectoral Frameworks for Community Development in Western Australia', Centre for Social Research, Edith Cowan University. Available at: http://www.ecu.edu.au/_data/assets/pdf_ file/0011/176735/CrossSector-Framework-CommDev-Nov2007.pdf. 
Pusey, M. 2008, 'In the Wake of Economic Reform ... New Prospects for NationBuilding?', in J. Butcher (ed.), Australia Under Construction, ANU E Press, Canberra.

QAO (Queensland Audit Office) 2007, 'Results of Performance Management Systems Audit of Management of Funding to Non-Government Organisations'. Available at: https://www.qao.qld.gov.au/files/file/Reports/2007\%20 Report\%20No.\%202.pdf.

Queensland 2007, 'Queensland Government Framework for Investment in Human Services', Queensland Government and the Futures Forum.

Queensland 2008, 'Compact Governance Committee Action Plan'. Available at:_http://www.pc.gov.au/_data/assets/pdf_file/0013/90022/sub156attachmentc.pdf.

Queensland 2009, 'The Queensland Compact: Annual Report 2009', Queensland Government and the Futures Forum.

Queensland 2010, 'The Queensland Compact Annual Report 2010', Queensland Government and the Futures Forum.

Queensland Government/Futures Forum 2008, 'The Queensland Compact: Towards a Fairer Queensland', Queensland Department of Communites, Child Safety and Disability Services.

Queensland Law Society 2012, 'Gag clauses concerning'. Available at: http:// www.qls.com.au/About_QLS/News_media/Media_releases/Gag_clauses_ concerning.

Rhodes, R. A. W. 2000, 'The Governance Narrative: Key Findings and Lessons from the ESRC's Whitehall Programme', Public Administration 78, pp. 345363.

Rhodes, R. A. W. 2007, 'Understanding Governance: Ten years on', Organisation Studies 28, pp. 1243-1264.

Sanders, W. 2008, 'In the Name of Failure: A generational revolution in Indigenous affairs', in C. Aulich and R. Wettenhall (eds) Howard's Fouth Government, UNSW Press, Sydney.

Shergold, P. 2008, 'Contracting Out Government: Collaboration or control?' Neil Walker Memorial Lecture, Centre for Social Impact, University of New South Wales.

Shergold, P. 2013, 'Service Sector Reform: A roadmap for community and human services reform', Final report, Melbourne VIC, Department of 
Human Services. Government of Victoria. Available at: http://www.dhs.vic. gov.au/_data/assets/pdf_file/0004/850108/Service-sector-reform-roadmapreport-shergold-2013.pdf. Accessed 23 September 2014 .

Simmons, B., F. Dobbin and G. Garrett 2006, 'Introduction: The international diffusion of liberalism', International Organization 60, pp. 781-810.

Singleton, G. 2001, 'Political Chronicles: Australian Capital Territory — January to June 2001', Australian Journal of Politics and History 47, pp. 585-593.

South Australia 2004, 'Common Ground', Department of Health and Department for Families and Communities, Government of South Australia.

South Australia 2009, 'Stronger Together: An agreement between the State Government of South Australia and the Health and Community Services Sector', SA Health and the Department for Families and Communities, Government of South Australia.

Tasmania 2012, 'Partnership Agreement between DHHS, DPAC and the Community Sector 2012-2015', Department of Human Services and Health and the Department of Premier and Cabinet, Government of Tasmania.

Treasury (NSW) 2012, 'Social Benefit Bonds Trial in NSW'. Available at: http:// www.treasury.nsw.gov.au/site_plan/social_benefit_bonds_trial_in_nsw_ FAQs.

VAGO (Victorian Auditor-General's Office) 2010, 'Partnering with the Community Sector in Human Services and Health'. Available at: http://www.audit.vic. gov.au/publications/2009-10/20100526-Community-Partnering-Full-Report. pdf.

VCOSS (Victorian Council of Social Service) 2006, 'Building a Strong and a Fair Community: Call to political parties 2006 Victorian State Election'. Available at: http://vcoss.org.au/document/building-a-strong-and-fair-communitycall-to-political-parties-2006-victorian-state-election/.

Victoria 2007a, 'Review of Not-for-Profit Regulation Final Report', State Services Authority. Available at: http://www.ssa.vic.gov.au/products/view-products/ review-of-not-for-profit-regulation.html.

Victoria 2007b, 'Stronger Community Organisations: Project report of the steering committee', Department of Planning and Community Development, Government of Victoria. Available at: http://www.vicsport.asn.au/ Association-Club-Support/SCOP/. 
Victoria 2009, 'Partnership Agreement between the Victorian Department of Education and Early Childhood Development and the Municipal Association of Victoria', Department of Education and Early Childhood Development, Government of Victoria.

Victoria 2010, 'Partnership Agreement Between the Department of Education and Early Childhood Development and the Victorian Community Sector 2010-2014', Department of Education and Early Childhood Development, Government of Victoria.

Webster, M. and C. I. Atkins 2011, 'Jeff's Agenda', Insight: Quarterly journal of the Victorian Council of Social Service, pp. 13-15.

Western Australia 2004, 'Industry Plan for the Non-Government Human Services Sector', Government of Western Australia.

Western Australia 2011a, '2011-12 Budget Overview', Government of Western Australia.

Western Australia 2011b, 'Delivering Community Services in Partnership Policy: A policy to achieve better outcomes for Western Australians through the funding and contracting of community services', Department of Premier and Cabinet, Government of Western Australia.

Wolch, J. 1990, The Shadow State: Government and voluntary sector in transition, The Foundation Center, New York.

\section{Personal Communications}

Personal communication 2010a, interview by author with senior NFP policy actor NSW, Sydney NSW, 17 November 2010.

Personal communication 2010b, interview by author with senior NFP policy actor QLD, Brisbane QLD, 20 December 2010.

Personal communication 2010c, interview by author with senior state policy officer NSW, Sydney NSW, 18 November 2010.

Personal communication 2010d, interview by author with senior state policy officer QLD, Brisbane QLD, 20 December 2010.

Personal communication 2010e, interview by author with senior state policy officer QLD, Brisbane QLD, 22 November 2010. 
Personal communication 2010f, interview by author with senior state policy officers NSW, Sydney NSW, 18 November 2010.

Personal communication 2011a, interview by author with senior NFP policy actor ACT, Canberra ACT, 1 April 2011.

Personal communication 2011 b, interview by author with senior NFP policy actor NSW, Sydney NSW, 13 September 2011.

Personal communication 2011c, interview by author with senior NFP policy actor SA, Adelaide SA, 6 July 2011.

Personal communication 2011d, interview by author with senior NFP policy actor TAS, Hobart TAS, 3 October 2011.

Personal communication 2011e, interview by author with senior NFP policy actor TAS, Hobart TAS, 4 October 2011.

Personal communication 2011f, interview by author with senior NFP policy actor VIC, Canberra ACT, 15 April 2011.

Personal communication $201 \mathrm{lg}$, interview by author with senior NFP policy actor WA, Perth WA, 4 July 2011.

Personal communication $2011 \mathrm{~h}$, interview by author with senior state policy officer ACT, Canberra ACT, 6 April 2011.

Personal communication 2011i, interview by author with senior state policy officer ACT, Canberra ACT, 31 April 2011.

Personal communication $2011 \mathrm{j}$, interview by author with senior state policy officer SA, Adelaide SA, 7 July 2011.

Personal communication $2011 \mathrm{k}$, interview by author with senior state policy officer SA, Adelaide SA, 21 July 2011.

Personal communication 2011l, interview by author with senior state policy officer TAS, Hobart TAS, 3 October 2011.

Personal communication $2011 \mathrm{~m}$, interview by author with senior state policy officer TAS, Hobart TAS, 4 October 2011.

Personal communication $2011 \mathrm{n}$, interview by author with senior state policy officer VIC, Melbourne VIC, 18 April 2011.

Personal communication 20110, interview by author with senior state policy officer WA, Perth WA, 5 July 2011. 
Personal communication $2011 \mathrm{p}$, interview by author with senior state policy officers NSW, Adelaide SA, 6 July 2011.

Personal communication 2011 , interview by author with senior state policy officers SA, Adelaide SA, 7 July 2011.

Personal communication 2013, meeting with senior government public officials ACT, 19 November 2013 
This text taken from New Accountabilities, New Challenges, edited by John Wanna, Evert A. Lindquist and Penelope Marshall, published 2015 by ANU Press, The Australian National University, Canberra, Australia. 